\title{
Assessment of coeliac disease prevalence in patients with Down syndrome in Poland - a multi-centre study
}

\author{
Anna Szaflarska-Popławska ${ }^{1}$, Anetta Soroczyńska-Wrzyszcz², Ewa Barg ${ }^{3}$, Jan Józefczuk4, Bartosz Korczowski ${ }^{5}$, \\ Urszula Grzybowska-Chlebowczyk ${ }^{6}$, Sabina Więcek ${ }^{6}$, Bożena Cukrowska ${ }^{7}$ \\ ${ }^{1}$ Department of Paediatric Endoscopy and Gastrointestinal Function Testing, Collegium Medicum in Bydgoszcz, \\ Nicolaus Copernicus University in Torun, Poland \\ ${ }^{2}$ Department of Paediatrics, Endocrinology, Cardiology and Neurology for Children and Adolescents, Regional Specialist \\ Hospital, Grudziadz, Poland \\ ${ }^{3}$ Department of Basic Medical Sciences, Wroclaw Medical University, Wroclaw, Poland \\ 4Paediatric Department with Children' Cardiological Subunit, Specialist Hospital of Holy Spirit, Sandomierz, Poland \\ ${ }^{5}$ Paediatric Department, Medical College, University of Rzeszow, Rzeszow, Poland \\ ${ }^{6}$ Department of Paediatrics, Gastroenterology Unit, School of Medicine, Medical University of Silesia, Katowice, Poland \\ ${ }^{7}$ Department of Pathology, Children's Memorial Health Institute, Warsaw, Poland
}

Prz Gastroenterol 2016; 11 (1): 41-46

DOI: $10.5114 / p g .2016 .57794$

Key words: coeliac disease, Down syndrome, prevalence, epidemiological study.

Address for correspondence: Prof. Anna Szaflarska-Popławska MD, PhD, Department of Paediatric Endoscopy and Gastrointestinal Function Testing, Nicolaus Copernicus University, Collegium Medicum, 9 M. Sklodowskiej-Curie St, 85-094 Bydgoszcz, Poland, phone: +48 525854850 , fax: +48 5258540 86, e-mail: aszaflarska@wp.pl

\begin{abstract}
Introduction: The results of studies assessing whether patients with Down syndrome have increased risk of coeliac disease are contradictory. The prevalence of coeliac disease in patients with Down syndrome is estimated at a wide range between $1 \%$ to as much as $18.6 \%$.

Aim: To assess coeliac disease prevalence in patients with Down syndrome in Poland.

Material and methods: The study enrolled 301 patients with Down syndrome from six centres in Poland (Wroclaw, Sandomierz, Rzeszow, Grudziadz, Katowice, and Bydgoszcz). We measured the concentration of anti-tissue transglutaminase IgA antibodies and anti-deamidated gliadin peptide IgG antibodies in all patients. Patients with abnormal positive $(>10 \mathrm{U} / \mathrm{ml})$ or inconclusive $(7-10 \mathrm{U} / \mathrm{ml})$ result of the serological test were offered endoscopic biopsy of the small intestine in the main centre.

Results: In 31 (10.3\%) patients increased concentrations of the investigated antibodies were found, including 19 (6.3\%) patients with increased tTg-IgA concentration, 27 (8.97\%) patients with increased concentration of DGP-IgG, and 15 (4.98\%) patients with increased concentration of both types of antibodies. Endoscopic biopsy of the small intestine was planned for all 31 patients with abnormal results of at least one antibody test and for 2 patients with inconclusive results. One of them suffered from previously diagnosed and histologically confirmed coeliac disease. Biopsy was not conducted in 9 patients due to contraindications, lack of their consent, or introduction of a gluten-free diet by the parents before the examination. In a group of 23 patients who underwent endoscopic biopsy of the small intestine, in 15 patients the histopathological picture of the small intestinal mucosa was typical for coeliac disease, 2 patients were diagnosed with lesions of grade 1 according to the classification by Marsh-Oberhuber, 1 patient was diagnosed with focal shortening of villi and hypertrophy of the crypts with no intraepithelial lymphocytosis (remains under gastrological observation), 2 patients were diagnosed with mucosal inflammation of the duodenum, and 3 patients were found to have a normal histopathological picture of the small intestine. Analysis of the data included in the questionnaires of all patients showed no statistically significant differences in the body height, body mass index, prevalence of abdominal pain, diarrhoea, constipations, recurrent stomatitis, enamel hypoplasia, thyroid diseases, or hypertransaminasaemia between the groups of patients with normal and abnormal serological test results. Significantly higher prevalence of abdominal flatulence $(p<0.05)$ and epilepsy $(p<0.05)$ was found in the group of patients whose serological test results were negative.

Conclusions: Patients with Down syndrome are a high-risk group for coeliac disease in the Polish population, with an estimated prevalence of at least 5.4\%. Serological tools based on TTG-IgA and DGP-lgG tests are useful for the diagnosis of coeliac disease in Down syndrome patients. tTG-IgA test may be superior to DGP-IgG test in patients with normal total IgA level. Tests for coeliac disease should be carried out in all Polish patients with Down syndrome, regardless of the clinical picture.
\end{abstract}




\section{Introduction}

Coeliac disease (CD) is a systemic disease of immunological aetiology, caused by gluten and gluten-related prolamines, in patients genetically predisposed to it. It is distinguished by diverse clinical manifestations and the presence of specific antibodies, haplotype DQ2 and/or DQ8 and enteropathy [1]. Occurrence of $C D$ is determined by mutual interactions of genetic and environmental factors. HLA-DQ2 histocompatibility antigens ( $A 1^{\star} 0501-B^{\star} 0201$ or $\left.A 1^{*} 0201-B^{*} 0202\right)$ and HLA-DQ8 (A ${ }^{\star} 0301-B 1^{\star} 0302$ ) occur in $95 \%$ and $5 \%$ of patients with $C D$, respectively. The presence of these antigens, though necessary, is not sufficient for CD to occur [2]. Genetic factors not only condition the occurrence of $C D$ but also determine its course. In patients being homozygote $\mathrm{DQB} 1{ }^{*} 02$ the onset of the disease is earlier and the risk of complications is higher [3]. The prevalence of $C D$, assessed based on a systematic review of literature is $1 / 160$ people in the overall population [4] with some regional differences, mostly related to different distribution of causal factors (level of gluten intake and frequency of HLA-DQ2 and HLADQ8) [5].

Scientific reports based on serological studies suggest that for every patient in whom the disease is diagnosed, 8 cases are estimated to go undetected [6]. Literature provides data stating that $C D$ is more frequent in patients with some autoimmunological and genetic diseases, compared to the overall population. The prevalence of $C D$ in patients suffering from type 1 diabetes mellitus assessed in numerous studies was $3-16 \%$ [7-11], the prevalence of CD in patients with an autoimmune thyroid disease was estimated at 2-4.4\% $[12,13]$, and the prevalence of CD in patients with autoimmune hepatitis was estimated at $13.5 \%$. Genetic syndromes associated with CD include Down, Turner's, and Williams syndrome [1].

Down syndrome (DS) is, in the general population, the most frequently occurring chromosomal aberration and the main genetic factor causing moderate mental impairment. The prevalence of DS is estimated at $1 / 800$ of life births [14]. Studies have shown that patients with DS suffer from immunological disturbances, are more susceptible to infections, and have higher risk of neoplasms and autoimmune diseases $[15,16]$. The most significant relation was detected for DS and autoimmune thyroiditis and $C D[17,18]$.

The first case of a patient with DS and coincident CD was described by Bantley in 1975 [19]. Since then, a more frequent occurrence of $C D$ in patients with DS was found in many countries. However, there has been no data concerning the coincidence of these two conditions in Poland.

\section{Aim}

The aim of the study was to assess the prevalence of $C D$ in patients with DS in the Polish population.

\section{Material and methods}

The study enrolled 301 patients with DS from 6 gastrological centres (Wroclaw, Sandomierz, Rzeszow, Grudziadz, Katowice, and Bydgoszcz), aged between 1 and 34 years. They were all on a gluten-containing diet. The group comprised 137 (45.5\%) females and 164 (54.5\%) males. Two hundred and forty-two patients had diagnosed regular trisomy, 9 patients had translocation trisomy, in 10 patients genetic test showed mosaicism, and in 40 cases the patient's guardians did not remember the result of the genetic test. After written consent had been obtained from the legal guardians of all patients, we measured the concentration of anti-tissue transglutaminase IgA antibodies and anti-deamidated gliadin peptide IgG antibodies, using the Phadia 100 system (ELiA, Thermo Fisher Scientific). The tests were performed in the Department of Pathology of the Children's Memorial Health Institute in Warsaw. Patients with positive (> $10 \mathrm{U} / \mathrm{ml}$ ) or possibly positive (7-10 U/ $\mathrm{ml}$ ) result of the serological test were offered endoscopic biopsy of the small intestine in the main centre. The microscopic picture of the biopsy samples of the small intestinal mucosa was assessed according to a modified classification by Marsh-Oberhuber [20].

At the moment of study enrolment all patients filled in a questionnaire concerning their body mass, height, clinical symptoms associated with CD, and co-morbidities. Due to the broad range of subjects' age, their body height was presented as height-standard deviation score (H-SDS) based on the following formula:

body height H-SDS $=\frac{\text { height of the child }- \text { height } 50 c}{\left.\frac{1}{2} \text { (height } 50 c-\text { height } 3 c\right)}$.

Similarly, body mass index (BMI) was presented as BMI-standard deviation score (BMI-SDS), which was based on the following formula:

BMI-SDS $=\frac{\text { BMI of the child }- \text { BMI 50c }}{\frac{1}{2} \text { (BMI 50c }- \text { BMI 3c) }}$.

The results of the comparison of questionnaire data of patients with negative (group 1) with positive and inconclusive results (group 2) of serological tests were analysed statistically.

\section{Statistical analysis}

Statistical analysis was carried out with use of Statistica programme by StatSoft. The probability of distribution of the analysed features to the normal distri- 
Table I. Results of serological tests in patients with Down syndrome

\begin{tabular}{|c|c|c|c|c|c|}
\hline $\begin{array}{l}\text { Number of } \\
\text { examined patients }\end{array}$ & $\begin{array}{l}\text { Number (\%) of } \\
\text { patients with } \\
\text { tTg-IgA (+) }\end{array}$ & $\begin{array}{l}\text { Number (\%) of } \\
\text { patients with } \\
\text { DGP-IgG (+) }\end{array}$ & $\begin{array}{c}\text { Number (\%) of } \\
\text { patients with } \\
\text { tTg-IgA (+) } \\
\text { DGP-IgG (+) }\end{array}$ & $\begin{array}{c}\text { Number (\%) of } \\
\text { patients with } \\
\text { tTg-IgA (+) } \\
\text { DGP-IgG (-) }\end{array}$ & $\begin{array}{l}\text { Number (\%) of } \\
\text { patients with } \\
\text { tTg-IgA (-) } \\
\text { DGP-IgG (+) }\end{array}$ \\
\hline 301 & 19 (6.3\%) & 27 (9.0\%) & $15(4.98 \%)$ & $4(1.3 \%)$ & $12(3.98 \%)$ \\
\hline
\end{tabular}

bution was verified with the Shapiro-Wilk test. If the distribution of the features was normal the $t$-Student test was used. For features not showing normal distribution (BMI-SDS) the Mann-Whitney test was applied.

\section{Results}

In 31 (10.3\%) patients increased concentration of the investigated antibodies was found, including 19 (6.3\%) patients with increased tTg-lgA concentration, $27(9.0 \%)$ with increased concentration of DGP-IgG, 15 (4.98\%) patients with increased concentration of both types of antibodies, and 12 (3.98\%) patients with only the DGP-IgG concentration being abnormal (Table I).

Endoscopic biopsy of the small intestine was planned for all 31 patients with a positive result of at least one antibody test and for 2 patients with a possible positive result. Biopsy of the small intestine was eventually performed in 23 patients. One person had a previously diagnosed and histologically confirmed CD. Small intestine biopsy was not performed in 9 patients due to the following reasons:

- earlier introduction of gluten-free diet by the parents (2 patients);

- lack of consent to a biopsy of the small intestine (4 patients);

- contraindications for biopsy of the small intestine

(3 patients; in all of them the concentrations of specific antibodies were normal; 1 patient had a confirmed genetic predisposition for $C D$ - the presence of haplotype HLA DQ2).

In a group of 23 patients who underwent endoscopic biopsy of the small intestine, 15 patients presented with intestinal changes typical for CD (confirmed in histopathological examinations of the small intestinal mucosa), such as villous atrophy, crypt hypertrophy, or intraepithelial lymphocytosis. Two patients were diagnosed with lesions of grade 1 according to a modified Marsh-Oberhuber classification, 1 patient was diagnosed with focal shortening of villi and hypertrophy of the crypts with no intraepithelial lymphocytosis (remains under gastrological observation), 2 patients were diagnosed with mucosal inflammation of the duodenum, and 3 patients were found to have a normal histopathological picture of the small intestine.

Comparison of the group of patients with negative results of serological tests (group 1) with the patients having positive or possibly positive results (group 2) revealed that the groups were similar as regards the sexes; however, patients from group 2 were statistically significantly older than those from group 1 (Table II). There were no statistically significant differences found between $\mathrm{H}$-SDS and BMI-SDS in the compared groups (Tables III and IV).

There were no statistically significant differences found in the prevalence of abdominal pain, diarrhoea, constipation, recurrent stomatitis, enamel hypoplasia, thyroid diseases, or hypertransaminasaemia between the compared groups. A significantly higher prevalence of abdominal flatulence $(p<0.05)$ and epilepsy $(p<0.05)$ was found in the group of patients whose serological test results were negative (Table $\mathrm{V}$ ).

\section{Discussion}

This study is the first one to assess the prevalence of CD in patients with DS in Poland. The results of the studies concerning the occurrence of CD in patients with DS in various populations differ significantly. They

Table II. Comparison of patients' age between groups 1 and 2

\begin{tabular}{|c|c|c|c|}
\hline \multirow[t]{2}{*}{ Parameters } & & \multicolumn{2}{|c|}{ Compared groups } \\
\hline & & Group 1 & Group 2 \\
\hline \multirow[t]{6}{*}{ Age } & $N$ & 266 & 33 \\
\hline & Min & 1.0 & 1.0 \\
\hline & Max & 34.0 & 24.0 \\
\hline & Median & 8.0 & 12.0 \\
\hline & Mean & 9.2 & 12.5 \\
\hline & SD & 6.55 & 5.95 \\
\hline \multirow{3}{*}{$\begin{array}{l}\text { Shapiro-Wilk } \\
\text { normality test }\end{array}$} & $W$ & - & 0.96 \\
\hline & $p$ & - & 0.3112 (NS) \\
\hline & $\begin{array}{l}\text { Normal } \\
\text { distribution }\end{array}$ & - & Yes \\
\hline \multirow{2}{*}{$\begin{array}{l}\text { Snedecor's F } \\
\text { distribution }\end{array}$} & $F$ & \multicolumn{2}{|c|}{1.21} \\
\hline & $p$ & \multicolumn{2}{|c|}{0.5211 (NS) } \\
\hline \multirow{2}{*}{$\begin{array}{l}\text { Student's } \\
t \text {-test }\end{array}$} & $t$ & \multicolumn{2}{|c|}{-2.78} \\
\hline & $p$ & \multicolumn{2}{|c|}{0.0058} \\
\hline
\end{tabular}


Table III. Comparison of SDS body height between groups

\begin{tabular}{|c|c|c|c|}
\hline \multirow[t]{2}{*}{ Parameters } & & \multicolumn{2}{|c|}{ Compared groups } \\
\hline & & Group 1 & Group 2 \\
\hline \multirow[t]{6}{*}{ HSDS } & $N$ & 247 & 31 \\
\hline & Min & -8.00 & -6.62 \\
\hline & Max & 4.000 & 1.200 \\
\hline & Median & -2.67 & -2.50 \\
\hline & Mean & -2.45 & -2.58 \\
\hline & SD & 1.821 & 2.042 \\
\hline \multirow{3}{*}{$\begin{array}{l}\text { Shapiro-Wilk } \\
\text { normality test }\end{array}$} & W & - & 0.97775 \\
\hline & $p$ & - & 0.74756 \\
\hline & $\begin{array}{l}\text { Normal } \\
\text { distribution }\end{array}$ & - & Yes \\
\hline \multirow{2}{*}{$\begin{array}{l}\text { Snedecor's F } \\
\text { distribution }\end{array}$} & $F$ & \multicolumn{2}{|c|}{1.2580} \\
\hline & $p$ & \multicolumn{2}{|c|}{0.3505 (NS) } \\
\hline \multirow{2}{*}{$\begin{array}{l}\text { Student's } \\
\text { t-test }\end{array}$} & $t$ & \multicolumn{2}{|c|}{0.3689} \\
\hline & $p$ & \multicolumn{2}{|c|}{0.7125} \\
\hline \multirow{2}{*}{$\begin{array}{l}\text { Mann-Whitney } \\
U \text { test }\end{array}$} & $U$ & \multicolumn{2}{|c|}{-} \\
\hline & $p$ & \multicolumn{2}{|c|}{-} \\
\hline
\end{tabular}

Table IV. Comparison of patients' BMI-SDS between groups

\begin{tabular}{|c|c|c|c|}
\hline \multirow[t]{2}{*}{ Parameters } & & \multicolumn{2}{|c|}{ Compared groups } \\
\hline & & Group 1 & Group 2 \\
\hline \multirow[t]{6}{*}{ BMI-SDS } & $N$ & 246 & 31 \\
\hline & Min & -8.04 & -3.80 \\
\hline & Max & 13.30 & 8.52 \\
\hline & Median & 0.733 & -0.006 \\
\hline & Mean & 1.439 & 0.930 \\
\hline & SD & 3.220 & 2.719 \\
\hline \multirow{3}{*}{$\begin{array}{l}\text { Shapiro-Wilk } \\
\text { normality test }\end{array}$} & W & - & 0.92919 \\
\hline & $p$ & - & 0.04167 \\
\hline & $\begin{array}{l}\text { Normal } \\
\text { distribution }\end{array}$ & - & No \\
\hline \multirow{2}{*}{$\begin{array}{l}\text { Snedecor's F } \\
\text { distribution }\end{array}$} & $F$ & \multicolumn{2}{|c|}{1.4031} \\
\hline & $p$ & \multicolumn{2}{|c|}{0.2671 (NS) } \\
\hline \multirow{2}{*}{$\begin{array}{l}\text { Student's } \\
t \text {-test }\end{array}$} & $t$ & \multicolumn{2}{|c|}{0.8422} \\
\hline & $p$ & \multicolumn{2}{|c|}{0.4004 (NS) } \\
\hline \multirow{2}{*}{$\begin{array}{l}\text { Mann-Whitney } \\
U \text { test }\end{array}$} & $U$ & \multicolumn{2}{|c|}{0.9291} \\
\hline & $p$ & \multicolumn{2}{|c|}{0.3529 (NS) } \\
\hline
\end{tabular}

Table V. Comparison of symptom prevalence between groups

\begin{tabular}{|c|c|c|c|c|c|c|c|c|c|}
\hline & & $\begin{array}{l}\text { Abdominal } \\
\text { pain }\end{array}$ & Diarrhoea & Constipation & Flatulence & $\begin{array}{l}\text { Recurrent } \\
\text { stomatitis }\end{array}$ & $\begin{array}{c}\text { Enamel } \\
\text { hypoplasia }\end{array}$ & Epilepsy & Other \\
\hline \multirow{2}{*}{$\begin{array}{l}\text { Group } 1 \\
\text { (268) }\end{array}$} & $n$ & 85 & 46 & 102 & 71 & 31 & 29 & 15 & 17 \\
\hline & $\%$ & 31.7 & 17.2 & 38.1 & 26.5 & 11.6 & 10.9 & 5.6 & 6.3 \\
\hline \multirow{2}{*}{$\begin{array}{l}\text { Group } 2 \\
\text { (33) }\end{array}$} & $n$ & 12 & 9 & 12 & 4 & 5 & 2 & 0 & 2 \\
\hline & $\%$ & 36.4 & 27.3 & 36.4 & 12.1 & 15.2 & 6.1 & 0.0 & 6.1 \\
\hline \multirow{3}{*}{$\begin{array}{l}\text { Test } \\
\text { for two } \\
\text { fractions }\end{array}$} & u & 0.5 & 1.4 & 0.2 & 1.9 & 0.6 & 0.9 & 2.0 & 0.1 \\
\hline & $p_{\text {two-sided }}$ & 0.5923 & 0.1701 & 0.8494 & 0.0570 & 0.5582 & 0.3684 & 0.0464 & 0.9139 \\
\hline & $p_{\text {one-sided }}$ & 0.2962 & 0.0851 & 0.4247 & 0.0285 & 0.2791 & 0.1842 & 0.0232 & 0.4570 \\
\hline
\end{tabular}

estimate that the prevalence of CD in people with DS ranges from $1 \%$ [21] up to as much as $18.6 \%$ [22].

Differences in the results can depend on the number of examined subjects and the criteria that are used in the diagnostic evaluation of CD. Low prevalence rate of $C D$ in patients with DS was found by Turkish researchers, Alanay et al., in 2005, who measured the IgAEmA antibodies in 100 patients with DS. A positive result was obtained in only 1 patient, biopsy of the small intestine was not performed due to lack of the patient's consent [21].
An exceptionally high prevalence rate of $C D$ in DS (12-18.6\%) was observed in Sweden and in the Czech Republic [22-24]. The study by Kolek et al. was conducted on a small group of only 25 patients with DS, which could be the cause of such a high percentage of patients with coincident DS and CD in this study [24]. The results obtained by the Swedish authors $[22,23]$ could be significantly affected by several factors, including higher prevalence of $C D$ in the overall population of Sweden $[25,26]$, the crite- 
Table VI. Comparison of prevalence of positive serological tests and histologically confirmed CD between the studied group and the overall population

\begin{tabular}{|c|c|c|c|c|c|c|c|}
\hline \multirow[t]{2}{*}{ Author } & \multirow{2}{*}{$\begin{array}{l}\text { Number of } \\
\text { patients in } \\
\text { the analysed } \\
\text { population }\end{array}$} & \multirow{2}{*}{$\begin{array}{c}\text { Number (\%) } \\
\text { of patients } \\
\text { with positive } \\
\text { serological test } \\
\text { results }\end{array}$} & \multicolumn{2}{|c|}{ Test for two fractions } & \multirow{2}{*}{$\begin{array}{l}\text { Number (\%) of } \\
\text { patients with } \\
\text { coeliac disease }\end{array}$} & \multicolumn{2}{|c|}{ Test for two fractions } \\
\hline & & & $u$ & $p$ & & $u$ & $p$ \\
\hline $\begin{array}{l}\text { Szaflarska-Popławska } \\
\text { et al. [35] }\end{array}$ & 3235 & $26(0.8 \%)$ & 13.2 & $<0.0001$ & $8(0.25 \%)$ & 10.2 & $<0.0001$ \\
\hline
\end{tabular}

ria applied in the study, or small number of investigated patients.

The prevalence of histologically confirmed CD in patients with DS in this study was at least $5.4 \%$ and is similar to the results obtained in other regions of the world. In a study carried out in Spain on a group of a similar size, CD was diagnosed in $6.3 \%$ of patients with DS [27]. In 2011 Bonamico et al. conducted a study including 1202 subjects. The study estimated the prevalence of CD among Italian patients with DS at 4.6\% [28]. George et al. estimated the prevalence of CD in Dutch children with DS at 7\% [29]. In three studies carried out in the USA this prevalence was $3.8 \%, 6.7 \%$, and $3.2 \%$ [30-32].

In the present study serological markers for $C D$ were found in 33 patients with DS (11\%). Similar prevalence (10.3\%) was obtained by Book et al., who investigated IgAEmA antibodies in children with DS living in the USA [33]. In our study all patients with recently diagnosed CD presented with tTG-IgA positivity, with one exception of a patient with a total IgA deficiency, who was DGP-IgG-positive. Patients who underwent biopsy of the small intestine and did not present with histological changes typical for CD were not tTG-IgA-positive (only DGP-IgG-positive), with the exception of 1 patient with a possibly positive result and 1 patient with positive but low tTG-IgA result $(37.6 \mathrm{U} / \mathrm{ml})$. This confirms that the tTG-IgA test in patients with DS seems to be a useful diagnostic tool and is probably superior to DGP-lgG test in patients with normal levels of total IgA [1].

In a study by Book et al., in patients with positive results for IgAEmA only, flatulence was the only symptom that was more prevalent than in IgAEmA-negative patients. There were no differences observed in body height, prevalence of diarrhoea, constipations, vomiting, or abdominal pain [33]. Bhat et al. assessed the prevalence of CD in Indian children with DS and they also took into account the clinical and laboratory parameters. They showed that among various clinical features assessed as possible risk factors for CD only paleness was statistically significantly more prevalent, and out of all laboratory parameters, only anaemia was significantly associated with CD [34]. The present study did not show any significant differences in the prevalence of abdominal pain, diarrhoea, enamel hypoplasia, or recurrent stomatitis. Only epilepsy and flatulence were more prevalent in the group of patients with negative serological test results. Thus, it seems that there is no one particular clinical parameter occurring in all patients with DS that would indicate that diagnostic evaluation of $C D$ is necessary.

A comparison (conducted with use of the test for two fractions) of prevalence of abnormal serological tests and histopathologically confirmed CD in the studied group with the prevalence in the Polish overall population [35] in children with DS, showed that the percentages were statistically significantly higher (Table VI). This indicates the necessity of conducting diagnostic evaluation for CD in all patients with Down syndrome.

\section{Conclusions}

Patients with DS are a high-risk group for CD in the Polish population, with an estimated prevalence of at least $5.4 \%$. Serological tools based on tTG-IgA and DGP-lgG tests are useful for the diagnosis of CD in DS patients. tTG-IgA test may be superior to DGP-lgG test in patients with normal total IgA level. Tests for CD should be carried out in all Polish patients with Down syndrome, regardless of the clinical picture.

\section{Conflict of interest}

The authors declare no conflict of interest.

\section{References}

1. Husby S, Koletzko S, Korponay-Szabó IR, et al. ESPGHAN Working Group on Coeliac Disease Diagnosis. ESPGHAN guidelines for the diagnosis of coeliac disease in children and adolescents. J Pediatr Gastroenterol Nutr 2012; 54: 136-60.

2. Green PH, Cellier C. Celiac disease. N Engl J Med 2007; 357: 1731-43.

3. Garrote JA, Gómez-González E, Bernardo D, et al. Celiac disease pathogenesis: the proinflammatory cytokine network. J Pediatr Gastroenterol Nutr 2008; 47: S27-32.

4. Biagi F, Klersy C, Balduzzi D, et al. Are we not over-estimating the prevalence of coeliac disease in the general population? Ann Med 2010; 42: 557-61. 
5. Catassi C, Gatti S, Fasano A. The new epidemiology of celiac disease. J Pediatr Gastroenterol Nutr 2014; 59 (Suppl.1): S7-9.

6. Hopper D, Hadjivassiliou M, Butt S, et al. Adult coeliac disease. BMJ 2007; 335: 558-62.

7. Uibo O, Heilman K, Rägo T, et al. Symptomless celiac disease in type 1 diabetes: 12-year experience in Estonia. Pediatr Intern 2010; 52: 230-3.

8. Frohlich-Reiterer EE, Hofer S, Kaspers S. Screening frequency for celiac disease and autoimmune thyroiditis in children and adolescents with type 1 diabetes mellitus - data from a German/Austrian multicentre survey. Pediatr Diabetes 2008; 9 546-53.

9. Boudraa G, Hachelaf W, Benbouabdellah M, et al. Prevalence of celiac disease in diabetic children and their first-degree relatives in West Algeria: screening with serological markers. Acta Paediatr Suppl 1996; 412: 58-60.

10. Salardi S, Volta U, Zucchini S. Prevalence of celiac disease in children with type 1 diabetes mellitus in the mid-1990s: an 18-year longitudinal study based on anti-endomysial antibodies. J Pediatr Gastroenterol Nutr 2008; 46: 612-4.

11. Żbikowska-Bojko M, Szaflarska-Popławska A, Pilecki O, et al. Selected aspects of the epidemiological analysis of celiac disease and diabetes mellitus type 1 coexistance in children and youth. Pol Merk Lek 2006; 20: 322-5.

12. Mainardi E, Montanelli A, Dotti M, et al. Thyroid-related autoantibodies and celiac disease: a role for a gluten-free diet? J Clin Gastroenterol 2002; 35: 245-8.

13. Meloni GF, Tomasi PA, Bertoncelli A, et al. Prevalence of silent celiac disease in patients with autoimmune thyroiditis from Northern Sardinia. J Endocrinol Invest 2001; 24: 298-302.

14. Pueschel SM. Physical characteristics, chromosome analysis and treatment approaches in Down syndrome. In: Down syndrome: a resource handbook. Tingey $C$ (ed.). College-Hill Press/ Little, Brown \& Co, Boston 1988; 3-21.

15. Nespoli L, Burgio GR, Ugazio AG, et al. Immunological features of Down's syndrome: a review. J Intel Disabil Res 1993; 37: 543-51.

16. Chistiakov D. Down syndrome and coexistent autoimmune diseases. J Appl Biomed 2007; 5: 71-6.

17. Shalitin S, Philip M. Autoimmune thyroiditis in infants with Down's syndrome. J Pediatr Endocrinol Metab 2002; 15: 649-52.

18. Regueras L, Prieto P, Muñoz-Calvo MT, et al. Endocrinological abnormalities in 1,105 children and adolescents with Down syndrome. Med Clin (Barc) 2011; 136: 376-81.

19. Bentley DA. A case of Down's syndrome complicated with retinoblastoma and coeliac disease. Pediatrics 1975; 56: 131-3.

20. Oberhuber G, Granditisch G, Vogelsang H. The histopathology of coeliac disease: time for a standardized report scheme for pathologists. Eur J Gastroenterol Hepatol 1999; 11: 1185-94.

21. Alanay Y, Boduroğlu K, Tunçbilek E. Celiac disease screening in 100 Turkish children with Down syndrome. Turk J Pediatr 2005; 47: 138-40.

22. Carlsson A, Axelsson I, Borulf S, et al. Prevalence of IgA-antigliadin antibodies and IgA-antiendomysium antibodies related to celiac disease in children with Down syndrome. Pediatrics 1998; 101: 272-5.

23. Jansson U, Johansson C. Down syndrome and celiac disease. J Pediatr Gastroenterol Nutr 1995; 21: 443-5.
24. Kolek A, Vospělová J, Hermanová Z, et al. Occurrence of coeliac disease in children with Down's syndrome in north Moravia, Czech Republic. Eur J Pediatr 2003; 162: 2007-8.

25. Ivarsson A, Persson LA, Nyström L, et al. Epidemic of celiac disease in Swedish children. Acta Paediatr 2000; 89: 165-71.

26. Myléus A, Ivarsson A, Webb C, et al. Celiac disease revealed in $3 \%$ of Swedish 12-year-olds born during an epidemic. J Pediatr Gastroenterol Nutr 2009; 49: 170-6.

27. Carnicer J, Farré C, Varea V, et al. Prevalence of coeliac disease in Down's syndrome. Eur J Gastroenterol Hepatol 2001; 13: 263-7.

28. Bonamico M, Mariani P, Danesi HM, et al. SIGEP (Italian Society of Pediatric Gastroenterology and Hepatology) and Medical Genetic Group. Prevalence and clinical picture of celiac disease in Italian Down syndrome patients: a multicenter study. J Pediatr Gastroenterol Nutr 2001; 33: 139-43.

29. George EK, Mearin ML, Bouquet J, et al. High frequency of celiac disease in Down syndrome. J Pediatr 1996; 128: 303-6.

30. Pueschel SM, Romano C, Failla P, et al. A prevalence study of celiac disease in persons with Down syndrome residing in the United States of America. Acta Paediatr 1999; 88: 953-6.

31. Zachor DA, Mroczek-Musulman E, Brown P. Prevalence of celiac disease in Down syndrome in the United States. J Pediatr Gastroenterol Nutr 2000; 31: 275-9.

32. Mackey J, Treem WR, Worley G, et al. Frequency of celiac disease in individuals with Down syndrome in the United States. Clin Pediatr 2001; 40: 249-52.

33. Book L, Hart A, Black J, et al. Prevalence and clinical characteristics of celiac disease in Down syndrome in a US study. Am J Med Genet 2001; 98: 70-4.

34. Bhat AS, Chaturvedi MK, Saini S, et al. Prevalence of celiac disease in Indian children with Down syndrome and its clinical and laboratory predictors. Indian J Pediatr 2013; 80: 114-7.

35. Szaflarska-Popławska A, Parzecka M, Muller L, et al. Screening for celiac disease in Poland. Med Sci Monit 2009; 15: PH 7-11.

Received: 28.01.2015

Accepted: 1.03.2015 